Article

\title{
The role of the church members and nurses in improving self-awareness to prevent HIV
}

\author{
Elysabeth Sinulingga, ${ }^{1}$ Agung Waluyo ${ }^{2}$ \\ ${ }^{1}$ Faculty of Nursing; ${ }^{2}$ Department of Medical Surgical Nursing, Faculty of Nursing, Universitas Indonesia, \\ Depok, West Java, Indonesia
}

\begin{abstract}
Background: Karo District is one of the districts in North Sumatera province where from 2016 to 2018 the number of HIV sufferers increased dramatically to 384 people and then it increased to 775 people up to September 2020. The aim of this study was to explore the experiences of people with HIV/AIDS and the experiences of the church members regarding people living with HIV/AIDS (PLWHA).

Design and Methods: Qualitative research design with descriptive phenomenology approach. Data collection was carried out by interviewing 34 participants in Karo District. The data analysis in this study used the Collaizi technique.

Results: Five themes were obtained from the results of the study, namely the responses of the participants diagnosed with HIV/AIDS, health problems faced by PLWHA, stigma and discrimination, the support of family and church members given to PWLHA, and family/church members' expectations toward PLWHA.

Conclusions: Based on the findings of the themes, the role of the National AIDS Commission of Moderamen Karo Batak Protestant Church (GBKP) in responding to HIV and AIDS cannot be optimally implemented because of some obstacles namely, localization which is a determinant of the spread of cases, the unavailability of service and ARV in all health centers, lack of sectoral cross-cooperation, very insufficient financial support from the government, the role of nurses played only in the hospitals and the stigmatism to those people with HIV/AIDS due to lack of knowledge of HIV and AIDS.
\end{abstract}

\section{Introduction}

Virus (HIV) is a virus that attacks the immune system. If HIV is not well treated, it can cause AIDS (acquired immunodeficiency syndrome) because when the virus attacks the human white blood cells, the body is very vulnerable to contagion. The retrovirus that integrates itself into the genetic material of the infecting cells alters the host cells. The main host cells for HIV are CD4 lympho- cytes that maintain the immune system. HIV/AIDS can be transmitted through sperms and vaginal fluids during sexual contact, the devices or needles contaminated with the HIV virus during shared injection drug use, transmission from mother to fetus, and HIV positive blood transfusions.

The United Nations in their program on HIV/AIDS stated that they had an estimation of 37,9 million people with HIV/AIDS around the world. Out of this number, 1,7 million of which were new cases. In Asia Pacific 5.9 million people were estimated to suffer from HIV : 46.000 people and AIDS: 640.000 people of which were new cases. ${ }^{1}$ Meanwhile in Indonesia during the fourth quarter, from October-December 2017, there were 14,640 new cases where the highest percentage of HIV risk factors was risky sex for heterosexuals (22\%), followed by homosexuals (21\%), use of unsterilized syringes in IDU (2\%), Whereas 4,725 people were reported to suffer from AIDS as new cases. ${ }^{2}$ In North Sumatera Province in particular there was a significant increase in the number of HIV positive and AIDS cases from 2015-2018. The recorded number of HIV cases consisted of $26.80 \%$ of women and $73.20 \%$ of men. Whereas the number of AIDS cases was recorded at $24.40 \%$ of women and $79.80 \%$ of men. ${ }^{3}$

Meanwhile according, up to August 2019 the North Sumatera Provincial Health Office had cumulatively recorded 9,362 HIV/AIDS cases consisting of 4,182 HIV cases and 5,180 AIDS cases. ${ }^{4}$ At the same time Mr Ramadhan, the secretariat of the National AIDS Commission of North Sumatera said that the number of HIV and AIDS cases in North Sumatera is still high with an upward trend in number. From January to September 2019 there were 71 people living with HIV AIDS in Karo District where there is one National AIDS Commission of Moderamen GBKP (Batak Karo Protestant Church).

Based on the initial interview with the head of the National AIDS Commission of Moderamen GBKP it was stated that the following actions have been taken: mentoring the HIV Commission in Kabanjahe by providing guidance counselors to 775 people comprising 340 referred clients, 25 child assistance, 164 people at the shelters, 130 case managers and 116 people for post rehabilitation. At present 96 clients ( 66 men and 30 women) are being mentored. The data shows that the performance of Moderamen GBKP in preventing HIV/AIDS has been maximized,

Significance for public health

The data shows that the performance of Moderamen GBKP in preventing HIV/AIDS has been maximized, but the awareness of church members to accept people living with HIV/AIDS (PLWHA) is still insufficient. Although education has been provided through churches and schools, there are some barriers from the community stigmatizing and discriminating PLWHA. In conclusion, the outreach and cross-sectoral cooperation related to HIV/AIDS prevention has not been maximal. Therefore, the number of PLWHA keeps increasing every year. This study wanted to see the HIV AIDS rate continues to rise annually due to lack of selfawareness to prevent HIV/AIDS, for which the government and local churches in Karo District have attempted to do so. 
but the awareness of church members to accept people living with HIV/AIDS (PLWHA) is still insufficient. Although education has been provided through churches and schools, there are some barriers from the community stigmatizing and discriminating PLWHA. In conclusion, the outreach and cross sectoral cooperation related to HIV/AIDS prevention has not been maximal. Therefore, the number of PLWHA keeps increasing every year. As a result of these problems, the HIV AIDS rate continues to rise annually due to lack of self-awareness to prevent HIV/AIDS, for which the government and local churches in Karo District have attempted to do so. The general objective of this study is to explore the experiences of the people living with HIV and AIDS, church members and nurses in the context of preventing HIV / AIDS transmission in Karo District.

\section{Design and Methods}

This research design used a qualitative phenomenological approach with data collection techniques completed through indepth interviews and document review of HIV/AIDS reports. The data analysis in this study used the Collaizi technique. The population and samples in this study were the people living with HIV/AIDS (PLWHA), the church members and Pastors. The place and time of the research were in Karo District, North Sumatera, from April to November 2020. In this study researchers were part of the research instrument. This study has been approved by ethics committee Faculty of Nursing Universitas Indonesia, Depok with number SK-276/UN.2.F12.D1.2.1/ETIK.FIK.2020. For respondent who participated in the research, fill out the Informed consent form. The respondents who agreed to participate in this study received a characteristic questionnaire to identify their characteristics, including age, sex, job, and phone number.

\section{Results}

\section{Characteristics of participants}

There were 34 participants aged between 17 and 70 in this study: 20 participants were men and 14 others were women. The education level of the participants varied greatly from junior high school (2 participants), senior high school (18 participants), school for nursing 2 participants, midwife nursing school (1 participant), undergraduate students (3 participants) and university graduates ( 8 participants). Among these 34 participants, there were students (4 participants), scavenger (2 participants), driver (1 participant), farmers (5 participants), businessmen (10 participants), state employees (2 participants), retired state employees (3 participants), private employees ( 3 participants), and Pastors (4 participants). Out of 34 participants, 8 lived with HIV/AIDS and 26 others were non PLWHA. 30 members of the GBKP congregation were among these 34 participants and 4 others were not. Among 8 PLWHA were 6 Christians, 1 Catholic and 1 Moslem. The characteristics of these participants can be seen in Table 1 .

\section{Health problems faced by PLWHA}

The problems experienced by PLWHA are physical, psychosocial, social, economic and spiritual problems. The obstacles faced by PLWHA are the problems that occur during experiencing HIV/AIDS in preventing transmission. The participants experience various obstacles that come from themselves, such as physical, psychological, economic, social, and spiritual state. These barriers can disrupt the life of PLWHA, their families, church members and communities. Participant's statement:

"I saw that those infected with HIV had characteristics such as cough, shortness of breath, weakness and pallor, I saw that their faces were moldy, their mouths cancer sores, chapped lips "(P.17);

“..... I'm not proud of myself anymore. I became low selfesteem person; I don't like health workers; they tell my brother about my illness. I tried hard to cover up my illness, no one knows. And now I feel sad. They come to my house, they don't want them

Table 1. Characteristics of study respondents: gender, age, education, PLWHA, occupation and profession.

\begin{tabular}{|c|c|c|}
\hline Participant characteristics & Sub-participant characteristics & Total \\
\hline Sex & $\begin{array}{l}\text { Male } \\
\text { Female }\end{array}$ & $\begin{array}{l}20 \\
14\end{array}$ \\
\hline Age & $\begin{array}{l}\text { Mean } \\
\text { Range }\end{array}$ & $\begin{array}{c}41 \\
17-70\end{array}$ \\
\hline Education & $\begin{array}{l}\text { Junior high school } \\
\text { High school } \\
\text { Nursing school (SPR) } \\
\text { Midwife } \\
\text { Undergraduate student } \\
\text { Graduates of higher education }\end{array}$ & $\begin{array}{l}2 \\
18 \\
2 \\
1 \\
3 \\
8\end{array}$ \\
\hline PLWHA & $\begin{array}{l}\text { Yes } \\
\text { No }\end{array}$ & $\begin{array}{c}8 \\
26 \\
\end{array}$ \\
\hline Employment status & $\begin{array}{l}\text { Student } \\
\text { Scavenger } \\
\text { Driver } \\
\text { Farmer } \\
\text { businessmen } \\
\text { state employees } \\
\text { Retired state employees } \\
\text { Private employees } \\
\text { Pastor }\end{array}$ & $\begin{array}{c}4 \\
2 \\
1 \\
5 \\
10 \\
2 \\
3 \\
3 \\
4\end{array}$ \\
\hline
\end{tabular}

All participants came from the Karo tribe (100\%). 
to eat and drink in my house. " (P.3); “... I still do good deeds to PLWHA but keep my distance and distance when I meet ... " (P.10); "I go to church every week but nobody knows that I have HIV, so I still feel comfortable praying ...” (P.1).

Physical barriers seek disease of the gestational system, respiratory system, system integument and genitalia. As to the social barriers it is related to family attitudes. Because PLWHA has physical problems, they cannot work and their financial stance is also affected. Below is the Participant's statement:

“... Initially I complained of nausea, vomiting, fever, diarrhea, and I looked skinny, then was treated at the Elfarina hospital. During treatment there was no improvement for my health and the nurse asked for an HIV test and then the result was positive and I was referred to public hospital. ..... "(P.1); “... I have seen people with HIV/AIDS with characteristics such as coughing, shortness of breath, weakness and pale, I saw their faces were moldy, ..........." (P.19).

\section{Stigma and discrimination}

The stigma and discrimination of the community / church members is still strong. The stigma that exists in society causes the patients to be isolated by their families and church / community members. Based on the interviews and observations, there is still a high level of negative attitudes from family, community and church members as evidenced by the results of the participant interviews:

"... I am afraid of getting infected and HIV is a dangerous disease, so they need to be placed in a certain place ..." (P.18, P.22, P26); "... the neighbors are also getting away from us if we are infected with HIV. People don't want to communicate with PLWHA because they are afraid of being infected" (P27).

\section{Support from family and church members to PLWHA}

In this theme, you will find families recognizing health problems, making decisions, caring for clients with HIV/AIDS, making environmental modifications and using health care facilities. Families in providing care support to PLWHA in this study were identified through participant statements regarding support in the treatment and care. Here is the result of the interview:

"There are families who care for their family members and provide treatment according to the needs of PLWHA, some bring them to the village to look for alternative medicine" tambar Kuta "to increase the patient's immune system. There are families who support treatment and some do not want to treat them so they isolate PLWHA for fear of contracting to other family members, but still provide medical expenses until they are healthy and can work again. If PLWHA is healthy, they farm again, if PLWHA does not have a job, we refer rehabilitation to the government for social services to participate in training and capital assistance ...

Based on the results of interview research, the support of families and church members for PLWHA is very good and field notes show that the support of church members and moderation of GBKP was through the formation of National AIDS Commission of Moderamen GBKP where the National AIDS Commission of Moderamen GBKP conducts preventing, mentoring, empowering activities; and owns a shelter. The activities carried out from the results of interviews with National AIDS Commission of Moderamen GBKP are as follows:

"........We always educate PLWHA every month so that they do not keep their health. The treatment we have is through the
Halfway House. We work together with hospitals and patients usually like to stop by, the services we provide nutritious food, there are therapies according to daily activities such as sweeping, mopping so that the muscles that are already stiff become good again. when it gets better, they farm again. For those who do not have a job, and refer to rehabilitation with the government, the social service division for training and capital assistance ...." (P.33)

\section{The expectation of the family and church members is culturally appropriate to prevent HIV transmission}

\section{The role of the health officer including the nurse}

The family and church members expect the health workers and services to perform properly so that the government programs to prevent HIV transmission can be improved. This is because the services in the hospitals and health centers are not optimal. Based on the results of the study the performance of HIV/AIDS officers at the Puskesmas (government-mandated community health clinics) was not optimal as evidenced by the results of the participant interviews:

"There are health workers and a team in the sub-district, but only 4 Puskesmas in Berastagi, Kabanjahe, Mardinding, Barusjahe, run properly although there are 17 Puskesmas that have been set up by the SIHA (HIV/AIDS Information System) team. This means 13 Puskesmas not running. Their reports are not available, even though there are some residents being treated for HIV / AIDS in the hospital .. "'(P.9).

Health officers (nurses) provide services for the patients at the Puskesmas, but they have not maximally provided services for the patients due to insufficient time, and there are still some obstacles for the health workers, for example they still work on priority. Therefore, the target of screening and finding targets for HIV positive sufferers have not been achieved. It was found out that there were some PLWHA patients who had been diagnosed with HIV/AIDS and treated at Kabanjahe and Adam Malik hospitals.

\section{Attitude of empathy for church and church members}

PLWHA participants hope to get a good and empathetical attitude from their family and church members in caring for them. The attitude is expected to be responsive, patient, attentive and undiscriminating. They should also have the motivation to keep up the spirit, to work well and appropriately. When they stay with their families, they want their family to give them empathetic care, thus giving them enthusiasm to live. The results of the interview are as follows:

"...now the family is very responsive to maintain my health and I also take care not to infect my wife ..." (P.1); "...Church members accept the conditions of PLWHA by visiting and praying" (P.14)

\section{Cultural factors}

Karo people are very attentive to their family and they love helping each other. The role of the church is to provide religious guidance and counseling according to Karo culture. Below is the result of the interview with the participants:

"... Karo culture has good customs where we support each other between family members so that we do not let any family members fall into spared bad behavior, such as becoming drug abusers. They support and love each other because of the same clan (family group)...” (P.22). 


\section{Discussion}

\section{The response of participants diagnosed with HIV/AIDS}

The results of this study indicate that the reactions for the first time being diagnosed with HIV/AIDS varied. The participants who heard that their church members or their families for the first time diagnosed with HIV showed denial reactions. They did not believe they were exposed to HIV disease, so they became shocked, and avoided the people around them with HIV. This is confirmed by the opinion by Kubler-Ross, ${ }^{5}$ which states that an individual's first reaction to the bad health is getting shocked and disbelieved.

Meanwhile it takes time for the people living with HIV/AIDS to accept themselves and their families diagnosed with HIV/AIDS. In this study, it was found that there was a response from PLWHA and their family or church members to accept their condition by helping to care for them and support them financially. According to Suddarth and Brunner acceptance of the person with HIV toward the condition. ${ }^{6}$ This will help maintain the quality of his life to plan for a better future. Because the quality of life is closely related to physical, psychological, spiritual and social health it is often measured in the evaluation of the impact of HIV interventions in different target populations. ${ }^{\text {? }}$

\section{Health problems faced by PLWHA}

The quality of life of PLWHA itself is quite susceptible to decline because of physiological as well as psychological problems. PLWHA is very susceptible to disease due to HIV infection which damages the immune system. This decline in the immune system will cause PLWHA to experience flu-like symptoms, such as: weakness, prolonged coughing, fever, headache, muscle aches, poor appetite, nausea, swollen glands, and patches on the skin. ${ }^{8}$

Pardita states that PLWHA are generally in a condition that makes them feel near death. ${ }^{9}$ Patients who are declared to have been infected with HIV will experience physical, psychological, social, and spiritual problems. The psychological problems that arise are stress, low self-esteem and anxiety. Whereas Ruth Beckmann Murray and Judith Proctor write that the spiritual dimension tries to be in tune with the universe, and strives for the answers about the infinite, and comes into focus when a person faces emotional stress, physical illness, or death. ${ }^{10}$

In this study, PLWHA paid attention to their cleanliness and did not let them get infected by their families. This study is in line with Rachmawati, who states that the level of awareness in maintaining health owned by all PLWHA is different because this is influenced by the attitude of each PLWHA in assessing health and how the PLWHA behaves in a clean and healthy life. ${ }^{11}$

\section{Stigma and discrimination}

The public's lack of understanding about HIV/AIDS is one of the factors causing stigma and discrimination. Stigma and discrimination will trigger human rights violations to occur among people living with HIV (PLHIV) and their families. Stigma and discrimination can lead to the severity of the HIV/AIDS epidemic. This will hamper efforts to prevent and fulfill the lack of access to HIV/AIDS services and treatment. ${ }^{12}$

According to Suddarth and Brunner, PLWHA often gets stigma due to the virus that infects them. PLWHA are often referred to as people who suffer from sexual or gay deviations, naughty women, and wrong relationships. ${ }^{6}$ Through this stigma, PLWHA are then ostracized and without realizing that this action has actually affected PLWHA's psychological condition. This has led PLWHA to the conditions of stress, depression, hopelessness. Likewise, with their families, families must be able to accept PLWHA with a big heart and do not discriminate against them, sometimes it is not easy to raise the spirit of PLWHA. This happens especially to PLWHA who are mentally weak, unable to accept the realities of life. ${ }^{13}$

Therefore, people living with PLWHA will exhibit levels of HIV-related stigma, ${ }^{14}$ which may be related to influence, behavior, and well-being among people living with HIV. ${ }^{15}$ Meanwhile, church members must also have knowledge on how to prevent HIV/AIDS by increasing the capacity of the church in helping PLWHA. This is in line with research in Nigeria, where the Church supports health promotion, capacity building, financial resources, social support, spiritual care, and denominational support. ${ }^{16}$

\section{Support from family and church members to PLWHA}

The findings of the research show that PLWHA is found out when they are already in the AIDS phase that allows them to receive a report or referral from the hospital and are referred to a halfway house because there is rejection from their family or families who are afraid to accept them in the same house. This research is in line with the research in India, where families or communities will provide support for isolation, separation or rejection so that the stigma of HIV/AIDS is known to reduce people's ability to access health services. ${ }^{17}$ If the family is not supportive, they can become anxious and depressed. Families need to provide support for their members who suffer from HIV/AIDS in order to prevent depression. ${ }^{18}$

Where the family will help solve problems for family members. People living with HIV/AIDS need support because this is a chronic disease and requires comprehensive treatment. ${ }^{19}$ Friedman, Bowden and Jones convey that one of the basic functions of the family is to fulfill the health of family members who are sick the goal of which is to meet family needs effectively. ${ }^{20}$ Caring in this study describes family activities in providing care to family members who are sick. This study is consistent with among PLHIV in India, reportedly causing stigma of discrimination, reduced access to care in health care settings, decreased adherence to ART due to fear of disclosure, and reduced disclosure rates to partners and families, potentially increasing the likelihood of transmission. $^{21}$

\section{The expectation of the family and church members is culturally appropriate to prevent HIV transmission}

Families and church members should be empathetic when providing care at home and in the hospital. The family's empathy attitude towards PLWHA will encourage them to live hopefully. They want to hang out and have many friends who can encourage them to fight against HIV/AIDS and of course they still have high dreams to achieve their goals. ${ }^{22}$

The families and church members hope that to prevent HIV using condoms when having sex is a must. Maintaining good relationships and being obedient to worship are also good ways to prevent HIV/AIDS transmission. This is reinforced by the results of the research that factors at the individual level are knowledge, motivation and readiness to consistently use condoms in adequate situations to prevent transmission. ${ }^{23} \mathrm{HIV}$ is a health problem, not a disgrace, so the importance of prevention and support is closely linked. HIV can affect anyone, so with good support the measures to prevent others from transmission will be successful if the patient feels comfortable with their family and society. ${ }^{24}$

Church members as well as Moderamen GBKP strongly support HIV prevention with the running program of the National AIDS Commission. This study is in line with several previous studies that have shown progress in integrating HIV prevention activities in churches in various places, including the United States 
and South Africa. ${ }^{25,26}$

HIV is a virus that damages the immune system by infecting and destroying CD4 cells. If HIV is not well treated, it can cause AIDS (acquired immunodeficiency syndrome) because when the virus attacks human white blood cells, the body is very vulnerable to contagion. The promotion of HIV/AIDS prevention is a program of the government and religious institutions. One of the ethnic Protestant religions also plays a role in HIV prevention and control through the National AIDS Commission of Moderamen GBKP.

Moderamen GBKP has improved communication, information, and education about HIV/AIDS increased the use of condoms, increased prevalence of sexually transmitted infections, increased prevention of mother-to-child HIV transmission and increased universal awareness. The Karo District Government has

Correspondence: Agung Waluyo, Department of Medical Surgical Nursing, Faculty of Nursing, Universitas Indonesia, Jalan Prof. Dr. Bahder Djohan, UI Depok Campus, Depok, West Java 16424, Indonesia. Tel. +62.21.78849120 - Fax: +62.21.7864124.

E-mail: agungwss@ui.ac.id

Key words: HIV knowledge; stigmatism; self-awareness; church; nurses.

Contributions: All authors contributed equally, have read and approved the final version of the manuscript and agreed to be accountable for all aspects of the work.

Conflict of interest: The authors declare no conflict of interest, financial or otherwise.

Acknowledgments: The author would thank all respondents and parties who had helped the completion of this research. Our deepest gratitude was also expressed to the Direktorat Riset dan Pengembangan Universitas Indonesia for funding this research with fund PUTI Saintekes 2020 Number: NKB-3447/UN2.RST/HKP.05.00/2020. Also, the authors are thankful to the National AIDS Commission of Moderamen GBKP in Karo District to allow us to conduct the research to complete the doctoral education tasks of medical surgical nursing specialists. We are also thankful to the Karo District health department for providing us with HIV/AIDS data.

Ethics approval and consent to participate: This study has been approved by the Ethics Committee of Faculty of Nursing Universitas Indonesia, Depok with Number: SK276/UN.2.F12.D1.2.1/ETIK.FIK.2020. For respondent who participated in the research, fill out the informed consent form.

Availability of data and materials: The datasets analyzed in this study are available from the corresponding author on reasonable request.

Conference presentation: This final manuscript has been presented at $7^{\text {th }}$ Virtual Biennial International Nursing Conference, Faculty of Nursing, Universitas Indonesia on September $24^{\text {th }}$, October $30^{\text {th }}$, November $16^{\text {th }} 2020$.

Received for publication: 15 August 2020.

Accepted for publication: 23 April 2021.

(c) Copyright: the Author(s), 2021

Licensee PAGEPress, Italy

Journal of Public Health Research 2021; 10(s1):2410

doi:10.4081/jphr.2021.2410

This work is licensed under a Creative Commons Attribution NonCommercial 4.0 License (CC BY-NC 4.0). made efforts to prevent VCT services and treatment of PLHIV. Moreover, besides that, in these efforts, there are prohibitions and challenges. The obstacles that occur are the low level of HIV knowledge, the lack of public awareness and understanding of the dangers of HIV/AIDS, and existing HIV/AIDS stigma and discrimination.

The church member and nurses should improve the health promotion efforts on HIV/AIDS through socialization in the churches and family service ('PJJ/Perpulungan Jabu-Jabu') to reduce stigma and discrimination against PLWHA. There is an increase in HIV/AIDS services in Puskesmas and in working with cross-sectoral and cross-religious. The District Government of Karo Programs are further improved to prevent the areas at risk of HIV transmission.

\section{References}

1. UNAIDs. UNAIDs data 2019. Geneva: UNAIDs. 2019. Available from: https:/www.unaids.org/en/resources/documents/2019/2019-UNAIDS-data

2. Ministry of Health of the Republic of Indonesia. [Situasi umum HIV/AIDS dan tes HIV (General HIV/AIDS situation and HIV test)].[in Indonesian]. Jakarta: Ministry of Health of the Republic of Indonesia. 2018.

3. North Sumatra Provincial Health Office. [Profil kesehatan Sumatera Utara 2018 (North Sumatra Health Profile 2018)].[in Indonesian]. Medan: North Sumatra Provincial Health Office. 2019.

4. Sitorus NAB. [Ada 9362 kasus HIV/AIDS di Sumatera Utara (There are 9,362 HIV/AIDS cases in North Sumatra)].[in Indonesian]. Antara News Sumut; 2019. Available from: https://sumut.antaranews.com/berita/261264/ada-9362-kasushiv-aids-di-sumut

5. Potter PA, Perry AG, Hall A, Stockert PA, editors Fundamentals of nursing. 9th ed. St. Louis: Mosby; 2017.

6. Smeltzer SCO, Bare BG, Hinkle JL, Cheever KH. Brunner \& Suddarth's textbook of medical-surgical nursing. Jakarta: Penerbit EGC; 2014.

7. Kabore I, Bloem J, Etheredge G, et al. The effect of community-based support services on clinical efficacy and health-related quality of life in HIV/AIDS patients in resource-limited settings in Sub-Saharan Africa. AIDS Patient Care ST 2010;24:581-94.

8. Greene K, Derlega VJ, Yep GA, Petronio S. Privacy and disclosure of HIV in interpersonal relationship: a sourcebook for researchers and practitioners. London: Lawrence Erlbaum Associates; 2003.

9. Pardita, DP. Analysis of the social, economic, and psychological impacts of HIV/AIDS patients in Denpasar City (unpublished Thesis). Denpasar: Universitas Udayana; 2014.

10. What is spirituality [Internet]. Minnesota: Taking Charge of your Health \& Wellbeing, Earl E. Bakken Center for Spirituality \& Healing, University of Minnesota; 2016.

11. Rachmawati, S. Kualitas hidup orang dengan HIV/AIDS yang mengikuti terapi antiretroviral (Quality of life for people with HIV/AIDS following antiretroviral therapy)].[Article in Indonesian]. Psychol J Sci Pract 2013;1:48-62.

12. Shaluhiyah Z, Musthofa SB, Widjanarko B. [Stigma Masyarakat terhadap Orang dengan HIV/AIDS (Community stigma against people living with HIV/AIDS)].[Article in Indonesian]. Jurnal Kesehatan Masyarakat Nasional 2015;9:333-9. 
13. Handajani YS, Djoerban Z, Irawan H, Ayu AP. Influence of depression to quality of life people living with HIV/AIDS after antiretroviral treatment. Medika 2014;2:96-101.

14. Mannheimer SB, Wang L, Wilton L, et al. Infrequent HIV testing and late HIV diagnosis are common among a cohort of black men who have sex with men in 6 US cities. J Acquir Immune Defic Syndr 2014;67:438-45.

15. Earnshaw VA, Smith LR, Chaudoir SR, et al. HIV stigma mechanisms and well-being among PLWH: a test of the HIV stigma framework. AIDS Behav 2013;17:1785-95.

16. Aja GN, Modeste NN, Lee JW, et al. Perceived church-based needs and assets for HIV/AIDS prevention in an urban Nigerian Community. J Relig Health 2010;49:50-61.

17. Zelaya CE, Sivaram S, Johnson SC, et al. Measurement of self, experienced, and perceived HIV/AIDS stigma using parallel scales in Chennai, India. AIDS Care 2012;24:846-55.

18. Martiningsih W, Kurnia FD, Winarni S. Hubungan dukungan keluarga dengan tingkat depresi pasien HIV/AIDS (The relationship between family support with depression levels for HIV/AIDS patients)].[Article in Indonesian]. Jurnal Ners dan Kebidanan 2015;2:130-5.

19. Li Y, Scott CS, Li L. Chinese nursing student's HIV / AIDS knowledge, attitude and practice intentions. Appl Nurs Res 2018;21:147-52.

20. Friedman MR, Bowden VR, Jones EG. Family nursing: research, theory and practice. New York: Pearson; 2003.

21. Chakrapani V, Newman PA, Shunmugam M, et al. Barriers to free antiretroviral treatment access for female sex workers in Chennai, India. AIDS Patient Care ST 2009;23:973-80.

22. Azizah IA. Kajian tentang sikap empati warga peduli AIDS dalam pencegahan dan penanggulangan HIV/AIDS sebagai warga negara yang baik)].[Unpublished Thesis in Indonesian]. Bandung: Universitas Pendidikan Indonesia; 2015.

23. Aditya ER. Perilaku penggunaan kondom secara konsisten untuk pencegahan HIV: suatu studi kualitatif pada pekerja seks laki-laki berbasis panti pijat di Jakarta (Consistent condom use behavior to prevent HIV; study qualitatively on male sex workers based on massage parlors in Jakarta)].[Unpublished Thesis in Indonesian]. Depok: Universitas Indonesia; 2012.

24. Green CW, Setyowati H. [Terapi alternatif (Alternative therapy)].[Book in Indonesian]. Jakarta: Yayasan Prima; 2004.

25. Mash R, Mash RJ. A quasi-experimental evaluation of an HIV prevention program by peer education in the Anglican Church of the Western Cape, South Africa. BMJ Open 2012;2: $\mathrm{e} 000638$.

26. Wingood GM, Simpson-Robinson L, Braxton ND, Raiford JL. Design of a faith-based HIV intervention: successful collaboration between a university and a church. Health Promot Pract 2011;12:823-31. 